\title{
Pengaruh Penggunaan Software Phet Sebagai Media Pembelajaran terhadap Hasil Belajar Fisika Ditinjau dari Kemampuan Awal Siswa Kelas X IPA SMA Negeri 1 Palibelo Tahun Ajaran 2017/2018
}

\author{
Asriyadin $^{1}$, Ice Puspitasari ${ }^{2}$, Endang Susilawati ${ }^{3}$ \\ ${ }^{1,2,3}$ STKIP Taman Siswa Bima \\ 1'asriyadin@gmail.com
}

\begin{abstract}
ABSTRAK
Penelitian ini bertujuan untuk mengetahui pengaruh penggunaan Software PhET sebagai media pembelajaran terhadap hasil belajar fisika ditinjau dari kemampuan awal siswa kelas X IPA SMA Negeri 1 Palibelo tahun ajaran 2017/2018. Penelitian ini merupakan penelitian eksperimen dengan rancangan penelitian menggunakan Pretest-Postest control group desaign dilaksanakan selama 1 bulan, subyek dalam penelitian ini adalah siswa kelas X IPA ${ }^{2}$ Sebagai kelas Eksperimen dan kelas X IPA ${ }^{3}$ sebagai kelas kontrol, dengan jumlah siswa untuk kelas Eksperimen dan Kontrol sebanyak 27 siswa. Teknik pengumpulan data yang digunakan yaitu tes hasil belajar, berupa tes pilihan ganda dan untuk mengetahui soal yang layak digunakan maka soal di uji validitas dan reliabilitas pada siswa kelas XI, soal yang diuji coba sebanyak 50 butir soal, dan di peroleh soal yang valid sebanyak 28 soal. Analisis data dalam penelitian ini adalah analisis kovarian menggunakan SPSS versi 16.0 maka di peroleh nilai Corrected Model $=0,00$ dengan taraf signifikan 0,05. Dari hasil perhitungan tersebut dapat disimpulkan bahwa ada Pengaruh Penggunaan Software PhET sebagai media pembelajaran Terhadap Hasil belajar fisika ditinjau dari kemampuan awal siswa kelas X IPA SMA Negeri 1 Palibelo tahun ajaran 2017/2018.
\end{abstract}

Kata Kunci: Software PhET, Hasil Belajar dan Kemampuan Awal.

\section{PENDAHULUAN}

Dalam usaha meningkatkan mutu pendidikan, banyak sekali faktor atau strategi yang bisa digunakan. Untuk dapat menerapkan strategi yang tepat, maka guru harus menguasai teknik-teknik penyajian dan beragam metode mengajar. Banyak faktor yang terlibat di dalam proses pembelajaran antara lain siswa, guru, sekolah, lingkungan masyarakat dan sebagainya.

Adapun faktor-faktor yang ikut menentukan keberhasilan siswa dalam mengikuti proses belajar pada siswa adalah kemampuan yang dimilikinya, motivasi, minat, kebiasaan, ketekunan, dan kualitas proses belajarnya. Sedangkan pada guru adalah kemampuan guru dalam mengajar, penguasaan materi, perencanaan program serta ketepatan guru dalam memilih teknik-teknik dan pendekatan tertentu dalam menyampaikan materi pelajarannya. Sedangkan pada sekolah adalah proses pengambilan keputusan, proses pengelolaan kelembagaan, proses pengelolaan program dan proses evaluasi belajar yang serba terkontrol. Sedangkan pada lingkungan masyarakat adalah pergaulan siswa dengan orang lain disekitarnya antara lain: Sifat-sifat orang tua, praktik pengelolaan keluarga, ketegangan keluarga, serta Kondisi masyarakat di lingkungan siswa yang kumuh, anak-anak penganggur dan serba kekurangan akan sangat mempengaruhi aktivitas belajar siswa. Siswa tersebut akan menemukan kesulitan ketika memerlukan teman belajar atau berdiskusi ataupun meminjam alatalat belajar tertentu yang kebetulan belum dimilikinya (Muhibbin Syah, 2003: 152-154).

Pelajaran fisika merupakan pelajaran yang tidak sekedar hafalan tetapi harus dipahami konsepnya. Siswa akan senang belajar fisika jika telah memahami keindahan danmanfaatnya. Ketika siswa sudah mulai tertarik, mereka akan bisa lebih mudah dalam menguasai fisika. Selain itu, jika materi yang sedang dibahas pernah dialami oleh siswa mungkin siswa akan dapat merekonstruksinya kembali menjadi pemahaman yang lebih baik. Oleh sebab itu, siswa diharapkan berusaha untuk memahami konsep yang mendasari suatu materi (Sadiman, 2008: 220-223). 
Mengingat pentingnya pemahaman tentang suatu konsep dalam pelajaran fisika, maka dibutuhkan media pembelajaran yang menyenangkan dan efektif. Penggunaan media pembelajaran dalam proses belajar mengajar dapat membangkitkan keinginan, minat yang baru, membangkitkan motivasi dan rangsangan kegiatan pembelajaran bahkan membawa pengaruh-pengaruh psikologis terhadap siswa (Arsyad, 2013:10). Media ini diharapkan dapat membantu efektifitas proses pembelajaran serta penyampaian pesan dan isi pelajaran sehingga siswa dapat meningkatkan pemahamannya tentang konsep-konsep fisika yang masih bersifat asbtrak agar mudah dipahami dan diaplikasikan dalam kehidupan sehari-sehari. Hal ini memungkinkan tercapainya tujuan pembelajaran, yang pada akhirnya dapat meningkatkan ketuntasan belajar.

Salah satu solusi alternatif media yang dapat digunakan untuk memudahkan pemahaman tentang konsep-konsep fisika yang bersifat abstrak adalah dengan menggunakan media pembelajaran software PhET. Software PhET merupakan program berbasis java yang menyenangkan dan interaktif. Tujuan pembelajaran fisika di kelas dengan menggunakan Software PhET yaitu menanamkan konsep fisika baik yang bersifat abstrak maupun konkret. Agus hariyanto (2016) dalam penelitiannya tentang "pengaruh discovery learning berbantuan paket program simulasi PhET terhadap prestasi belajar fisika”, juga mengatakan bahwa lingkungan pembelajaran yang bermedia teknologi dapat meningkatkan nilai para siswa (konsep), sikap mereka terhadap belajar dan evaluasi dari pengalaman belajar mereka. Media pembelajaran menggunakan software PhET yang berbasiskan komputer dapat dijadikan sebagai media alternatif dalam meningkatkan kemampuan siswa.

Dari hasil wawancara dengan Ibu Siti Nurhasanah S.Pd selaku guru mata pelajaran fisika di SMA Negeri 1 Palibelo bahwa proses pembelajaran yang diterapkan di sekolah tersebut khususnya di kelas X IPA menggunakan metode diskusi, eksperimen, dan demonstrasi serta sumber dan media yang digunakan dalam proses belajar mengajar adalah media aplikasi power point dan animasi lingkungan yang ditampilkan menggunakan LCD proyektor serta buku dan internet sebagai sumber belajar di kelas X IPA tersebut. Dari penggunaan media, model, dan sumber belajar tersebut, siswa beranggapan bahwa mata pelajaran fisika itu sulit dan membuat siswa terkadang tidak memahami materi yang diajarkan oleh guru tersebut dan dibuktikan dari siswa yang tidak bertanya pada saat proses pembelajaran. Kurangnya pemanfaatan laboratorium juga membuat siswa tidak semangat dan kurang aktif dalam proses pembelajaran sehingga mengakibatkan hasil belajar fisika siswa menurun.

Hal ini diindikasikan sebagai faktor penyebab tujuan pembelajaran tidak dapat tercapai, yang ditunjukkan dari nilai ulangan harian siswa kelas X IPA pada semester I di SMA Negeri 1 Palibelo tahun ajaran 2017/2018 dimana masih banyak yang memperoleh nilai di bawah KKM (Kriteria Ketuntasan Minimum), dimana KKM untuk pelajaran fisika di SMA Negeri 1 Palibelo adalah 6,5, untuk itu digunakan cara yang tepat dalam menangani masalah tersebut. Dalam hal ini peneliti menggunakan Software PhET sebagai media dalam proses pembelajaran. Penggunaan media Software PhET ini sudah lama diterapkan disekolah-sekolah ternama di kota-kota lainnya. Tetapi penggunaan Software PhET ini di anggap baru bagi sekolah-sekolah yang ada di kabupaten bima khususnya SMA Negeri 1 Palibelo. Dengan menggunakan media ini, tentu siswa semangat dalam proses belajar mengajar, serta siswa dapat mengetahui penggunaan media ini sehingga siswa tidak merasa bosan dan menganggap bahwa belajar fisika itu menyenangkan. Perpaduan antara prinsip-prinsip dan penggunaan media dalam pengajaran akan menghasilkan pengajaran yang efektif dan mampu meningkatkan ketertarikan dan pemahaman terhadap pelajaran fisika, sehingga diharapkan dapat meningkatkan hasil belajar Fisika siswa.

Berdasarkan uraian pada latar belakang di atas, peneliti menerapkan pembelajaran dengan menggunakan Media Pembelajaran Software 
PhET Terhadap Hasil Belajar Fisika Ditinjau dari Kemampuan Awal Siswa Kelas X IPA SMA Negeri 1 Palibelo Tahun Ajaran 2017/2018”.

\section{Media Pembelajaran}

Prinsip pembelajaran yang baik adalah jika seseorang belajar mengembangkan konsep generalisasi, bahan abstrak dapat menjadi hal yang jelas dan nyata. Sumber belajar yang digunakan pengajar dan anak adalah buku-buku dan informasi, tetapi akan lebih jelas dan efektif jika pengajar menyertai dengan berbagai media pengajaran yang dapat membantu menjelaskan bahan lebih realistik.

AH. Sanaky (2009: 23) menyatakan bahwa media pembelajaran adalah sebuah alat yang berfungsi dan digunakan untuk menyampaikan pesan pembelajaran.Pembelajaran adalah proses komunikasi antara pembelajar, pengajar dan bahan ajar. Dapat dikatakan bahwa, bentuk komunikasi tidak akan berjalan tanpa bantuan sarana untuk menyampaikan pesan. Bentukbentuk stimulus dapat dipergunakan sebagai media, diantaranya adalah hubungan atau interaksi manusia, realitas, gambar bergerak atau tidak, tulisan dan suara yang direkam.

Banyak batasan atau pengertian yang dikemukakan para ahli tentang media, diantaranya adalah Asosiasi Teknologi dan Komunikasi Pendidikan atau Association of Education and Communication Technology atau (AECT) di Amerika, membatasi media sebagai segala bentuk dan saluran yang digunakan orang untuk menyalurkan pesan atau informasi.

Dari pengertian di atas dapat disimpulkan bahwa media pembelajaran adalah sarana pendidikan yang dapat digunakan sebagai perantara dalam proses pembelajaran untuk mempertinggi efektifitas dan efisiensi dalam mencapai tujuan pengajaran.

\section{Software PhET}

PhET adalah sebuah software media pembelajaran yang di dalamnya terdapat beberapa materi simulasi pembelajaran fisika untuk kepentingan pengajaran di kelas atau dapat digunakan untuk kepentingan belajar individu. Simulasi yang disediakan PhET sangat interaktif, mengajak siswa untuk belajar dengan cara mengeksplorasi secara langsung. Software
PhET ini membuat suatu animasi fisika yang abstrak atau tidak dapat dilihat oleh mata telanjang, seperti: atom, elektron, foton dan medan magnet. Untuk eksplorasi secara kuantitatif, software PhET ini memiliki alat-alat ukur di dalamnya seperti penggaris, stopwatch, voltmeter dan termometer (Carl, 2011: 97).

Program simulasi PhET merupakan media simulasi interaktif menyenangkan berbasis penemuan berupa software dan dapat digunakan untuk memperjelas konsep-konsep fisis atau fenomena yang telah dipraktikumkan (Mubarrok \& Mulyaningsih, 2014: 76-80). Pembelajaran dengan menggunakan simulasi PhET membuat siswa tertarik dan semangat melakukan praktikum sehingga menuntaskan hasil belajar siswa (Prihatiningtyas,2013: 18-22). Di samping itu pembelajaran fisika dengan menggunakan multimedia interaktif PhET memberikan hasil belajar lebih baik daripada kelas yang hanya menggunakan praktikum saja tanpa disertai penggunaan media PhET (Mubarrok \& Mulyaningsih, 2014: 76-80).

Manfaat dari simulasi PhET yang telah diuji dapat diuraikan sebagai berikut: 1) Dapat dijadikan suatu pendekatan pembelajaran yang membutuhkan keterlibatan dan interaksi dengan siswa; 2) Memberikan feedback yang dinamis; 3) Mendidik siswa agar memiliki pola berfikir kontruktivisme, dimana siswa dapat menggabungkan pengetahuan awal dengan temuan-temuan virtual dari simulasi yang dijalankan; 4) Membuat pembelajaran lebih menarik karena siswa dapat belajar sekaligus bermain pada simulasi tersebut; 5) Menvisualisasi konsep-konsep fisika dalam bentuk model. Seperti elektron, photon, molekul dll.

\section{Kemampuan Awal}

Kemampuan awal merupakan hasil belajar yang didapat sebelum mendapat kemampuan yang lebih tinggi. Kemampuan awal siswa merupakan prasyarat untuk mengikuti pembelajaran sehingga dapat melaksanakan proses pembelajaran dengan baik. Kemampuan seseorang yang diperoleh dari pelatihan selama hidupnya, dan apa yang dibawa untuk menghadapi suatu pengalaman baru. 
Perencanaan pembelajaran tidak lepas dari variabel-variabel pembelajaran. Glaser mengemukakan seperti yang dikutip Hamzah B. Uno (2011: 15) bahwa pembelajaran memiliki empat komponen, yaitu analisis isi bidang studi, diagnosis kemampuan awal siswa, proses pembelajaran, dan pengukuran hasil belajar. Salah satu yang memiliki peran penting sebagai dasar penentuan proses pembelajaran adalah diagnosis kemampuan awal (Recognition of Prior Learning).

Judy Harris (2000: 1) menerangkan bahwa Diagnosis kemampuan awal perlu diperlukan untuk mengetahui pengetahuan atau pembelajaran yang telah didapatkan seseorang baik secara formal maupun tidak formal. Pengetahuan akan kemampuan awal seseorang perlu diketahui agar proses pembelajaran dapat selaras antara guru dan siswa.

Kemampuan awal digunakan tidak hanya untuk keselarasan dalam proses pembelajaran, namun juga memiliki peran penting lainnya. Hamzah B.Uno (2011: 58) menerangkan bahwa kemampuan awal amat penting peranannya dalam meningkatkan kebermaknaan pengajaran, yang selanjutnya membawa dampak dalam memudahkan proses-proses internal yang berlangsung dalam diri siswa ketika belajar. Telah dijelaskan di atas bahwa sebelum pembelajaran dilakukan, guru harus mengetahui karakteristik awal dari kemampuan awal dari siswanya, salah satunya yaitu kemampuan awal siswa.

\section{Hasil Belajar}

Hasil belajar merupakan kemampuan yang dimiliki peserta didik setelah menempuh proses belajar (Yus'iran, Asriyadin, \& Wahyuni, 2017). Hal ini mengisyaratkan bahwa objek yang di nilainya adalah hasil belajar siswa. Hasil belajar siswa pada hakikatnya merupakan perubahan tingkah laku setelah melalui proses belajar mengajar. Tingkah laku sebagai hasil bealajar dalam pengertian luas mencakup bidang kognitif, efektif dan psikomotorik. Penilaian dan pengukuran hasil belajar dilakukan dengan menggunakan tes hasil belajar, terutama hasil belajar kognitif berkenaan dengan penguasaan bahan pengajaran sesuai dengan tujuan pendidikan dan pengajaran. Walaupun demikian, tes dapat digunakan untuk mengukur atau menilai hasil belajar dibidang afektif dan psikomotorik (Sudjana, 2005: 15).

Menurut (Sudjana, 2005: 105) mengutarakan tujuan penilaian hasil belajar sebagai berikut: 1) Mendeskripsikan kecakapan belajar siswa sehingga dapat diketahui kelebihan dan kekurangannya dalam berbagai bidang studi atau mata pelajaran yang di tempuhnya. Dengan pendeskripsian kecakapan tersebut dapat diketahui pula posisi kemampuan siswa dibandingkan dengan siswa lainnya; 2) Mengetahui keberhasilan proses pendidikan dan pengajaran disekolah, yakni seberapa jauh keefektifannya dalam mengubah tingkah laku siswa kearah tujuan pendidikan yang diharapkan; 3) Menentukan tindak lanjut hasil penilaian, yakni melakukan perbaikan dan penyempurnaan dalam hal program pendidikan dan pengajaran serta system pelaksanaannya; 4) Memberikan pertanggung jawaban (accountability) dari pihak sekolah kepada pihakpihak yang berkepentingan.

\section{METODE PENELITIAN \\ Jenis Penelitian}

Jenis penelitian yang digunakan adalah penelitian eksperimen. Penelitian eksperimen merupakan metode penelitian yang digunakan untuk mencari pengaruh perlakuan tertentu terhadap yang lain dalam kondisi yang terkendalikan. Penelitian eksperimen meneliti ada tidaknya hubungan sebab akibat serta seberapa besar hubungan sebab akibat tersebut dengan cara memberi perlakuan tertentu pada beberapa kelompok eksperimen dan menyediakan kontrol untuk perbandingan (Sugiyono,2009:107). Rancangan penelitian menggunakan Pretest-Postes Control group desaign.

\section{Tempat dan Waktu Penelitian}

Penelitan ini dilaksanakan pada semester ganjil mulai tanggal 15 September - 14 Oktober 2017 di SMA Negeri1 Palibelo Tahun Ajaran 2017/2018.

\section{Populasi dan Sampel Penelitian}

Dalam penelitian ini yang menjadi populasi adalah kelas X IPA SMA Negeri 1 Palibelo. 
Dalam penelitian ini yang menjadi sampel penelitian adalah kelas X IPA $^{2}$ sebagai kelas Eksperimen dan kelas X IPA ${ }^{3}$ sebagai kelas kontrol. Adapun teknik pengambilan sampel yang digunakan adalah cluster random sampling.

\section{Variabel Penelitan}

Variabel Bebas, Dalam penelitian ini, yang menjadi variabel bebas adalah penggunaan media Software PhET dengan media Power Point.

Variabel Terikat, Dalam penelitian ini yang menjadi Variabel terikat adalah hasil belajar fisika siswa.

Variabel kontrol, Dalam penelitian ini yang menjadi Variabel kontrol adalah Kemampuan awal (kovarian).

\section{Teknik Pengumpulan Data}

Teknik Tes, Teknik Tes digunakan dalam penelitian ini adalah tes tertulis berbentuk pilihan ganda. Soal tes pilihan ganda digunakan untuk mengetahui kemampuan awal dan hasil belajar fisika siswa.

Teknik Non Tes, Teknik Non Tes digunakan dalam penelitian ini adalah wawancara, dokumentasi, dan perangkat pembelajaran seperti silabus dan RPP.

\section{Instrumen penelitian}

Instrumen penelitian adalah suatu alat yang digunakan untuk mengukur fenomena alam maupun sosial yang diamati secara spesifik, fenomena yang dimaksud adalah variabel penelitian (Sugiyono, 2009:102). Instrument yang digunakan dalam penelitian ini yaitu berupa soal tes untuk mengetahui hasil belajar siswa. Tes yang digunakan dalam penelitian ini adalah tes tertulis berbentuk pilihan ganda. Soal tes pilihan ganda digunakan untuk mengetahui kemampuan awal dan hasil belajar fisika siswa. Soal yang digunakan adalah 50 soal pilihan ganda.

\section{Validitas dan Reliabilitas Instrumen}

Menurut Arikunto (2010: 73), bahwa baik buruknya tes (tes pilihan ganda) diukur dengan menguji validitas dan reliabilitas.

Validitas disebut dengan istilah keshahihan. Validitas butir soal dapat dicari dengan korelasi point biserial.

Analisis reliabilitas suatu tes pada dasarnya adalah menguji keajegan pertanyaan tes. Untuk mencari reliabilitas soal digunakan rumus $\mathrm{K}$ R20 (Sugiyono, 2012: 359).

Untuk mengetahui tingkat reliabilitas soal, dibandingkan dengan kriteria reliabilitas berikut:

\begin{tabular}{cc}
\multicolumn{2}{c}{ Tabel 1. Kriteria Reliabilitas: } \\
\hline Nilai & Kategori \\
\hline $0,81-1,00$ & Sangat Tinggi \\
$0,61-0,80$ & Tinggi \\
$0,41-0,60$ & Cukup tinggi \\
$0,21-0,40$ & Rendah \\
$0,00-0,20$ & Sangat rendah \\
\hline
\end{tabular}

\section{Teknik Analisis Data}

Analisis data dalam penelitian ini dilakukan dengan teknik statistik inferensial yaitu teknik statistik yang digunakan untuk menganalisis data sampel dan hasilnya diberlakukan untuk populasi (Sugiyono, 2010: 21).

\section{Uji Prasyarat}

Uji homogenitas dimaksudkan untuk mendeteksi seragam atau tidak variansi sampelsampel yang diambil dari populasi yang sama. Uji homogenitas akan sangat penting jika hasil penelitian ingin digeneralisasikan untuk populasi. (Ridwan, 2010: 179). Uji homogenitas data dapat dicari dengan menggunakan uji-F.

Uji normalitas dilakukan dengan tujuan untuk mengetahui apakah data tes hasil belajar dan kemampuan awal terdistribusi normal atau tidak.rumus untuk menentukan normal atau tidaknya soal dengan menggunakan uji chi kuadrat.

\section{Uji Hipotesis}

Pengujian hipotesis dimaksudkan untuk menjawab hipotesis yang telah di ajukan untuk maksud tersebut, maka pengujian dilakukan dengan menggunakan uji analisis kovarian.

\section{HASIL DAN PEMBAHASAN}

\section{Uji Coba Instrumen}

Uji coba instrumen dilaksanakan pada tanggal 15 September 2017 di kelas XI SMA Negeri 1 Palibelo. Untuk mendapatkan instrumen yang baik, maka dalam penelitian ini telah dilakukan uji validitas dan uji reliabilitas.

Instrumen yang diuji coba sebanyak 50 butir soal, diperoleh soal yang valid memenuhi tiap indikator materi pelajaran yang diukur yaitu 28 soal yang valid dan 22 soal yang tidak valid. Untuk reliabilitas diperoleh bahwa $r_{\mathrm{I}}=0,62$, ini 
berarti reliabilitas soal termasuk pada kategori tinggi (Lihat Tabel 1). Jumlah soal yang dapat digunakan untuk uji tes hasil belajar sebanyak 28 butir soal.

\section{Deskripsi Data}

Pelaksanaan pre-test dilakukan pada awal penelitian atau pekan pertama penelitian dengan memberikan soal pre-test sedangkan pelaksanaan post-test dilakukan pada akhir penelitian atau pekan terakhir penelitian. Data pada proses pretest diperoleh nilai rata-rata siswa pada kelas kontrol sebesar 33,56, sedangkan pada kelas eksperimen nilai rata-rata siswa sebesar 39,78. Hal ini menggambarkan bahwa kemampuan awal siswa masih rendah. Sedangkan data pada proses post-test setelah diberikan perlakuan pada kelas eksperimen terjadi peningkatan nilai yang diperoleh siswa, dimana nilai rata-rata siswa pada kelas eksperimen meningkat menjadi 73,00 sedangkan kelas kontrol yang tidak diberikan perlakuan nilai rata-rata yang diperoleh siswa hanya 61,00.

Tabel 2. Hasil belajar siswa pada kelas eksperimen dan kontrol

\begin{tabular}{ccc}
\hline \multirow{2}{*}{ Nilai } & \multicolumn{2}{c}{ Rata-rata } \\
\cline { 2 - 3 } & Kelas Ekperimen & Kelas Kontrol \\
\hline Pre test & 39,78 & 33,56 \\
\hline
\end{tabular}

\section{Data Hasil Uji Analisis}

Uji homogenitas dilakukan untuk mengetahui homogen atau tidaknya kedua kelas setelah diberikan perlakuan. Hasil uji homogenitas dapat dilihat pada Tabel 3.

Tabel 3. Data Hasil Uji Homogenitas Pre-Test

\begin{tabular}{ccccc}
\hline Kelas & $\mathrm{N}$ & $F_{h}$ & $F_{t}$ & Ket \\
\hline Eksperimen & 27 & 1,19 & 1,94 & Homogen \\
\hline Kontrol & 27 & & & \\
\hline
\end{tabular}

Berdasarkan Tabel 3. terlihat bahwa $F_{\text {hitung }}<$ $F_{\text {tabel }}$ pada taraf signifikan $5 \%$. Hal ini berarti kedua kelas dikatakan homogen sebelum diberikan perlakuan.

Tabel 4. Data Hasil Uji Homogenitas Post-Test

\begin{tabular}{ccccc}
\hline Kelas & $\mathrm{N}$ & $F_{h}$ & $F_{t}$ & Ket \\
\hline Eksperimen & 27 & 1,32 & 1,94 & Homogen \\
\hline Kontrol & 27 & & & \\
\hline
\end{tabular}

Berdasarkan Tabel 4. terlihat bahwa $F_{\text {hitung }}<$ $F_{\text {tabel }}$ pada taraf signifikan $5 \%$. Hal ini berarti kedua kelas dikatakan homogen setelah diberikan perlakuan.
Uji normalitas dilakukan untuk mengetahui kedua kelas terdistribusi normal atau tidak. Hasil uji normalitas dapat dilihat pada Tabel 5 .

Tabel 5. Data Hasil Uji Normalitas pre-test Kelas Eksperimen dan Kelas Kontrol

\begin{tabular}{cccc}
\hline Kelas & $X^{2}{ }_{h}$ & $X^{2}{ }_{t}$ & Kriteria \\
\hline Eksperimen & 4,59 & 7,815 & Normal \\
\hline Kontrol & 4,39 & 7,815 & Normal \\
\hline
\end{tabular}

Berdasarkan Tabel 5. dapat dilihat bahwa $X_{\text {hitung }}^{2}<X_{\text {tabel }}^{2}$ sehingga disimpulkan bahwa nilai pre-test kedua kelas terdistribusi normal.

Tabel 6. Hasil Uji Normalitas post- test Kelas Eksperimen Dan Kelas Kontrol

\begin{tabular}{cccc}
\hline Kelas & $\chi_{{ }_{h}}^{2}$ & $\chi^{2}$ & Kriteria \\
\hline Eksperimen & 5,56 & 7,815 & Normal \\
\hline Kontrol & - & 7,815 & Normal
\end{tabular}

$$
33,62
$$

Berdasarkan Tabel 6 dapat dilihat bahwa $X_{\text {hitung }}^{2}<X_{\text {tabel }}^{2}$ sehingga disimpulkan bahwa nilai post-test kedua kelas terdistribusi normal.

\section{Data Uji Hipotesis}

Uji hipotesis dianalisis menggunakan SPSS untuk melihat ada pengaruh dan hubungan dari kemampuan awal dengan hasil belajar menggunakan media Sofware PhET tersebut.

Tabel 7. Data Hasil Analisis kovarian

\begin{tabular}{lrrrrrr}
\hline \multicolumn{1}{c}{ Source } & $\begin{array}{l}\text { Type III } \\
\text { Sum of } \\
\text { Squares }\end{array}$ & Df & $\begin{array}{c}\text { Mean } \\
\text { Square }\end{array}$ & F & Sig. \\
\hline $\begin{array}{l}\text { Corrected } \\
\text { Model }\end{array}$ & $2673.263^{\mathrm{a}}$ & 2 & 1336.632 & 14.830 & .000 \\
\hline \begin{tabular}{l} 
Intercept \\
\hline $\begin{array}{l}\text { Kemampua } \\
\mathrm{n} \text { Awal }\end{array}$
\end{tabular} & 729.263 & 1 & 729.263 & 8.091 & .048 \\
\hline Media & 1192.901 & 1 & 1192.901 & 13.235 & .001 \\
\hline Error & 4596.737 & 51 & 90.132 & & \\
\hline Total & 249676.00 & 54 & & & & \\
\hline
\end{tabular}

Corrected

Total

7270.00053

a. $R$ Squared $=, 368$ (Adjusted $R$ Squared $=, 343$ )

Berdasarkan Tabel 7 maka nilai Corrected Model adalah 0,00 dengan taraf signifikan 0,05. Maka dapat disimpulkan bahwa $H_{0}$ di tolak dan $H_{a}$ di terima.

\section{Pembahasan}

Penelitian ini termasuk penellitian eksperimen yang bertujuan menguji secara langsung pengaruh suatu variabel terhadap 
variabel lainnya, dimana dalam hal ini variabel bebas yaitu media Software PhET dan Powerpoint. Dimana Media Sofware PhET yang merupakan variabel perlakuan dan variabel terikat yaitu Hasil Belajar sedangkan kemampuan awal merupakan variabel kovarian. Dalan penelitian ini terdapat dua kelas sampel yaitu, kelas X IPA ${ }^{2}$ (eksperimen) dan kelas X IPA $^{3}$ (kontrol). Sebelum melakukan penelitian, peneliti terlebih dahulu menyiapkan instrumen penelitian seperti perangkat pembelajaran (Silabus, RPP, LDS, dan soal tes hasil belajar). Perangkat penelitian disesuaikan dengan materi pokok yang diajarkan (Gerak Lurus) dan sumber belajar yang diterapkan baik pada kelas eksperimen maupun kelas kontrol. Instrumen soal tes hasil belajar yang digunakan dalam penelitian ini 28 butir soal objektif.

Pada awal penerapan Media Sofware PhET, guru memberikan pre test pada kelas X IPA ${ }^{2}$ dengan jumlah 27 siswa untuk mengetahui kemampuan awal siswa sebelum diberikan pembelajaran dengan mengunakan media Software PhET, kemudian data yang di dapat diuji Homogenitas dan normalitasnya untuk mengetahui apakah data homogen dan normal.

Tahap pendahuluan guru memberikan apersepsi serta tujuan dari pembelajaran yang berhubungan dengan materi agar siswa siap dalam mengikuti mata pelajaran yang akan dipelajari.

Tahap inti dalam Penggunaan Media Sofware PhET dimulai dari tahap pertama yaitu guru mengakses media Software PhET yang berkaitan dengan materi yang akan diajarkan pada website yang telah ditentukan yaitu: http://www.Phet.colorado.edu, siswa mengikuti langkah-langkah yang dilkukan oleh guru dalam mengakses materi dengan menggunakan website yang sama, tahap kedua guru membagi siswa dalam beberapa kelompok diskusi dan membagikan LDS kepada setiap kelompok, tahap ketiga siswa melakukan diskusi dengan angggota kelompok yang telah ditentukan, tahap keempat guru mengontrol jalannya diskusi supaya diskusi berjalan dengan aman dan tertib.

Tahap penutup dalam pembelajaran ini guru bersama siswa mengevaluasi proses pelaksanaan kegiatan pembelajaran, dan menyampaikan informasi materi pada pertemuan berikutnya.

Berdasarkan data yang diperoleh dalam penelitian ini, instrumen yang digunakan yaitu instrumen pilihan ganda, untuk mendapatkan data penggunaan media Software PhET dilakukan pre-test dan post-test. Data pada proses pre-test, diperoleh nilai rata-rata siswa pada kelas kontrol sebesar 33,56 dengan skor tertinggi 46 dan skor terendah 17 sedangkan pada kelas eksperimen nilai rata-rata siswa sebesar 39,78 dengan skor tertinggi 61 dan skor terendah 21. Hal ini disebabkan karena pengetahuan awal siswa masih rendah. Sedangkan data pada proses posttest setelah diberikan proses pembelajaran dengan menggunakan Media Software PhET pada kelas eksperimen terjadi peningkatan nilai yang diperoleh siswa, dimana nilai rata-rata siswa pada kelas eksperimen meningkat menjadi 73,00 dengan nilai tertinggi 92 dan nilai terendah 53 . Sedangkan kelas kontrol yang diterapkan menggunakan Media Powerpoint nilai rata-rata yang diperoleh siswa hanya 61,00 dengan nilai tertinggi 78 dan nilai terendah 46.

Setelah dilakukan penelitian selama 1 bulan untuk kemudian mengumpulkan data-data akurat yang berhubungan dengan kebutuhan penelitian, maka dilakukan uji kovarian menggunakan SPSS didapatkan bahwa kemampuan awal 0,18. Karena nilai signifikan kurang dari 0,05 maka $H_{o}$ ditolak, dan dapat dikatakan ada hubugan linear antara kemampuan awal dengan hasil belajar yang diperoleh siswa. Kemudian untuk nilai signifikan media pembelajaran sebesar 0,01. Karena nilai signifikan kurang dari 0,05 maka $H_{o}$ ditolak. Sehingga dapat disimpulkan tanpa adanya kemampuan awal tentu berpengaruh terhadap hasil belajar siswa. Dan untuk Corrected Model diperoleh nilai signifikansi sebesar 0,00. Karena nilai signifikan jauh di bawah 0,05 maka $H_{o}$ ditolak. Dan dapat disimpulkan secara bersama-sama ada perbedaan media pembelajaran dan kemampuan awal yang mempengaruhi hasil belajar siswa. Serta diperoleh nilai $R$ Square adalah 0,368 artinya hanya $36 \%$ dari hasil belajar yang digunakan. Sehingga dapat disimpulkan bahwa media 
pembelajaran dan kemampuan awal berpengaruh terhadap hasil belajar siswa. Selain itu, ada variabel lain yang mempengaruhi media dan kemampuan awal yang tidak masuk dalam penelitian.

Sedangkan penelitian pada kelas kontrol X IPA $^{3}$ dengan jumlah 27 siswa dilakukan menggunakan Media Powerpoint yaitu mengajar dengan menjelaskan menggunakan slide yang ada di Powerpoint dimana peneliti berperan sebagai penyampai informasi dan siswa sebagai penerima informasi, serta penyampaian materi pembelajaran secara langsung menggunakan Powerpoint, hasilnya pemahaman yang dimiliki oleh siswa kurang karena, siswa hanya sekedar mendengarkan dan melihat cara guru menyampaikan materi yang diajarkan. Pembelajaran seperti ini terkesan kurang bermakna dan membatasi pemikiran siswa. Siswa tidak bisa mengeksplorasi ide-idenya karena telah terpaku pada pola pengajaran guru menyampaikan materi yang diajarkan. Pembelajaran seperti ini terkesan kurang bermakna dan membatasi pemikiran siswa. Siswa tidak bisa mengeksploitasi ide-idenya karena telah terpaku pada pola pengajaran guru. Pada akhirnya, siswa akan sangat tergantung pada guru, lebih-lebih dalam memecahkan masalah yang kompleks.

Hasil penelitian menunjukkan bahwa terdapat perbedaan antara kelas eksperimen yang menggunakan media Software PhET dengan kelas kontrol yang menggunakan media Powerpoint. Hal tersebut terjadi karena siswa tertarik dan termotivasi untuk belajar dengan penggunaan media Software PhET mampu membangun komunikasi yang baik antara guru dan siswa begitu pun siswa dengan siswa lainya, dimana sebelumya guru mengajar secara langsung dengan menjelaskan materi yang terdapat di media Powerpoint sedangkan siswa mendengarkan dan mencatat hal-hal yang dianggap penting dan mengerjakan latihan soal yang diberikan oleh guru. Guru belum memanfaatkan media pembelajaran yang sesuai dan menarik bagi siswa dan kurang mengikuti perkembangan dunia pendidikan, sehingga siswa dalam proses pembelajaran cenderung pasif dan kurang memahami materi karena hanya menerima informasi dan mendengar.

Media merupakan sarana penyalur pesan informasi belajar yang hendak disampaikan oleh sumber pesan kepada sasaran atau penerima tersebut. Penggunaan media pengajaran dapat membantu pencapaian keberhasilan belajar. Hal ini sejalan dengan pendapat (Sudarwan, 2014: 29) bahwa hasil penelitian telah banyak membuktikan efektivitas penggunaan alat bantu atau media dalam proses belajar mengajar di kelas, terutama dalam hal peningkatan hasil belajar siswa.

Selain itu, dari hasil penelitian yang dilakukan oleh Ahmad ibn Abd al-Rahman alSamiraa'I (2014), ditemukan bahwa tingkat pencapaian pengetahuan melalui indera penglihatan mencapai $75 \%$, sementara melalui indera pendengaran hanya $13 \%$, sedangkan melalui indera lain, seperti pengecapan, sentuhan, penciuman, pengetahuan hanya dapat diperoleh sebesar 12\%. Lingkungan belajar yang dilengkapi dengan gambar-gambar memberikan dampak 3 kali lebih kuat dan mendalam dari pada kata-kata. Hal ini memungkinkan menjadi penyebab perbedaan hasil belajar kelas eksperimen mendapatkan pembelajaran yang memadukan kata-kata dan gambar sehingga hasil belajar lebih baik dan siswa yang hanya belajar dengan metode ceramah. Hal ini sejalan dengan Yasmaruddin Bardansyah (2008: 34) mengatakan bahwa media pembelajaran yang dapat memadukan kata-kata (suara) dan gambar diyakini dan terbukti memberikan peran penting dalam menunjang efektifitas pembelajaran yang dilakukan oleh guru.

Media Software PhET memberikan banyak manfaat salah satunya yaitu siswa bisa lebih memahami proses pembelajaran karena siswa tidak saja mendengarkan secara langsung materi yang akann dipelajari tetapi mereka dapat melihat dan mencoba sendiri media yang digunakan dalam proses pembelajaran. Dari paparan di atas, maka semakin jelas bahwa media pengajaran merupakan kebutuhan yang tidak dapat dielakkan dalam rangka menyukseskan program belajar siswa agar dapat 
tercapai perubahan tingkah laku yang diharapkan.

Perencanaan pembelajaran tidak lepas dari variabel-variabel pembelajaran. Salah satu yang memiliki peran penting sebagai dasar penentuan proses pembelajaran adalah diagnosis kemampuan awal. Judy Harris (2000: 1) menerangkan diagnosis kemampuan awal diperlukan untuk mengetahui kemampuan awal dalam proses pembelajaran yang didapatkan seseorang baik secara formal maupun tidak formal. Pengetahuan akan kemampuan awal seseorang perlu diketahui agar proses pembelajaran dapat selaras antara guru dan siswa.

Kemampuan awal digunakan tidak hanya untuk keselarasan dalam proses pembelajaran, namun juga memiliki peran penting lainnya. Martini Yamin (2007: 32) mengungkapkan salah satu manfaat yang dapat diperoleh dari hasil kajian siswa yang akan kita hadapi di dalam kelas adalah kita memperoleh ganbaran yang lengkap dan terperinci tentang kompetensi atau kemampuan awal para siswa yang berfungsi sebagai prerequisite bagi bahan materi baru yang akan disampaikan. Telah dijelaskan di atas bahwa sebelum pembelajaran dilakukan, guru harus mengetahui karakteristik awal dari siswanya, salah satunya yaitu kemampuan awal siswa.

Berdasarkan uraian di atas, melalui penggunaan media Software PhET dengan menggunakan analisis kovarian dapat mengatasi masalah guru dan siswa dalam hal proses pembelajaran serta keterbatasan penggunaan media pembelajaran. Hal demikian dapat berpengaruh terhadap hasil belajar siswa sehingga pembelajaran fisika semakin lama akan semakin membaik.

\section{KESIMPULAN}

Berdasarkan hasil yang diperoleh dari penelitian ini, hipotesis $H_{0}$ ditolak dan $H_{a}$ diterima. Dengan demikian dapat disimpulkan bahwa penggunaan Software PhET sebagai media pembelajaran terhadap hasil belajar fisika ditinjau dari kemampuan awal siswa kelas X IPA
SMA Negeri 1 Palibelo Tahun Ajaran 2017/2018.

\section{DAFTAR PUSTAKA}

Agus, Hardiansyah. 2016. "Pengaruh Discovery Learning Berbantuan Paket Program Simulasi Phet Terhadap Prestasi Belajar Fisika" dalam Jurnal Pendidikan dan Kebudayaan, Vol 1,Nomor 3 Desember 2016.

AH. Sanaky, Hujair. 2009. Media Pembelajaran. Yogyakarta: Safiria Insania Press.

Arikunto. 2010. Prosedur Penelitian: Suatu Pendekatan Praktik. (Edisi Revisi). Jakarta: Rineka Cipta.

Arief S. Sadiman, dkk. 2008. Media Pendidikan. Jakarta: PT Raja Grafindo Persada.

Colorado. 1998. “ Simulasi PhET”. Tersedia pada http: //www.phet.colorado.edu, diakses Jum'at, 25 Agustus 2017, pukul 16.43 Wita.

Danim, Sudarwan, 1995. Media Komunikasi Pendidikan. Bumi Aksara. Jakarta.

Hamzah B. Uno. 2011. Perencanaan Pembelajaran. Jakarta: PT. Bumi Aksara.

Haris, Judy. 2000. RPL: Power Pedagogy and Possibility. Diunduh dari http://books.google.com pada tanggal 30 Mei 2013, jam 16.08.

Mubarrok, M. F. \& Mulyaningsih, S. 2014. "Penerapan Pembelajaran Fisika pada Materi Cahaya dengan Media PhET Simulations untuk Meningkatkan Pemahaman Konsep Siswa di SMP” dalam Jurnal Inovasi Pendidikan Fisika, 3 (1), 76-80.

Muhammat, E. D. Y. 2015. "Pengaruh Penerapan Media Pembelajaran Phet (Physics Education Technology) Simulation Terhadap Hasil Belajar Siswa Kelas X TITL Pada Standar Kompetensi Mengaplikasikan Rangkaian Listrik di SMKN 7 Surabaya” dalam Jurnal Pendidikan Teknik Elektro. Volume 04 Nomor 02, 407-414.

Prihatiningtyas, S., Prastowo, T., \& Jatmiko, B. 2013. "Implementasi Simulasi PhET dan Kit Sederhana untuk Mengajarkan Keterampilan Psikomotor Siswa pada Pokok 
Bahasan Alat Optik" dalam Jurnal Pendidikan IPA Indonesia JPII, 2 (1), 18-22.

Ridwan. 2010. Statistika untuk Penelitian. Bandung: Alfabeta.

Sudjana. 2005. Proses Perkembangan Hasil Belajar. Bandung: cv Pustaka Pelajar.

Sugiyono. 2009. Metode Penelitian Kuantitatif Kualitatif dan REDD. Bandung: Alfabeta. 2010. Statistika Untuk Penelitian. Bandung: Alfabeta.

2012. Metode Penelitian Kombinasi (mixed Methods). (Edisi II). Bandung: Alfabeta.

Wahana Komputer. 2005. Penembangan Analisis Multivariat dengan SPSS. 12. Jakarta: Salembah Infotek.

Yasmaruddin, Bardansyah. 2008. Urgensi Penciptaan Lingkungan Berbahasa Asing. Jakarta.

Yus'iran, Y., Asriyadin, A., \& Wahyuni, N. (2017). Perbedaan Penerapan Pendekatan Concept Mapping dan Pendekatan Inquiri Role terhadap Hasil Belajar Fisika. Gravity: Jurnal Ilmiah Penelitian dan Pembelajaran Fisika, 3(2), 198-207. 